\title{
HUBUNGAN PEMAKAIAN KONTRASEPSI SUNTIK DENGAN KEJADIAN AMENOREA DIWILAYAH KERJA PUSKESMAS ATARI JAYA KECAMATAN LALEMBUU KABUPATEN KONAWE SELATAN TAHUN 2015
}

\author{
Wahida $^{1}$, Listyan utami ${ }^{2}$ \\ ${ }^{1}$ Dosen Jurusan Kebidanan Poltekkes Kemenkes Kendari \\ ${ }^{2}$ Mahasiswa Jurusan Kebidanan Poltekkes Kemenkes Kendari
}

\begin{abstract}
Background: Amenorrhoea is no occurrence of menstruation for 3 months or more in women who have experienced menstrual cycles. Some cases of amenorrhea can be found in injectable contraceptive acceptors. This is confirmed by the data from Southeast Sulawesi province that there are 284,784 and 201,627 (70.8\%) among them experiencing amenorrhea.

Objective: To find out whether there is a relationship between injectable contraception and the incidence of amenorrhea in the work area of Atari Jaya Health Center, Lalembuu District, South Konawe Regency in 2015.

Research methods: Analytical research with adesign crossstudy. The sample in this study amounted to 92 injectable contraceptive acceptors. This research uses accidental sampling technique. Data analysis included univariate and bivariate analysis using the SPSS (Chi Square test) program at the level of confidence $\alpha=0.05$.

Results: Amenorrhoea is a complaint that is often felt in injectable contraceptive acceptors. Of the 92 injectable contraceptive acceptors who suffered secondary amenorrhoea there were $59(64.1 \%)$ acceptors while $33(35.9 \%)$ acceptors did not suffer from secondary amenorrhoea. This shows that the value of $\rho=0,000$ is smaller than the value of $\alpha=0.05$. Then there is the relationship of injectable contraception with the incidence of amenorrhea.

Conclusion: There is a correlation between injectable contraceptive use and the incidence of amenorrhea in the work area of Atari Jaya Community Health Center, Lalembuu Subdistrict, South Konawe Regency in 2015.

Suggestion: For injection contraceptive acceptors who experience abnormal menstrual changes, they should always counsel health workers in the nearest service agency.
\end{abstract}

Keywords: injection contraception, amenorrhoea

\section{PENDAHULUAN}

Amenorea merupakan keadaan tidak terjadinya menstruasi 3 bulan berturut-turut. Amenorea primer adalah tidak terjadinya menarse sampai 17 tahun, dengan ataupun perkembangan seksual sekunder. Amenorea skunder merupakan tidak terjadinya menstruasi selama 3 bulan atau lebih pada wanita yang penah mengalami siklus menstruasi.

Sebagian besar wanita Indonesia memilih alat kontrasepsi berdasarkan pengaruh dan pengalaman orang yang sudah memakainya. Padahal tidak satupun metode kontrasepsi yang aman dan efektif bagi semua klien karena masing-masing mempunyai kesesuaian dan kecocokan individu setiap klien. Setelah mendapatkan penyuntikan ada sebagian akseptor kontrasepsi suntik menyadari ketidak normalan siklus haidnya, yaitu ibu tidak mendapatkan haid tiap bulannya setelah penyuntikan (Sarwono, 2008).

Pemakaian suntik sebagai kontrasepsi hormonal tidak menimbulkan efek permanen terhadap fertilitas (kesuburan). Akan tetapi, kembalinya kesubur pada wanita akan kembali tertunda karena terkait dengan lama pemakaian kontrasepsi tersebut.Amenorhea dapat menyebabkan seorang wanita menjadi tidak subur.Menstruasi yang normal menandakan bahwa Anda subur dan organ-organ tubuh Anda bekerja dengan baik.Jika seorang wanita tidak mengalami menstruasi, dapat diketahui bahwa seorang wanita sedang mengalami gangguan 
pada sistem reproduksinya dan memiliki kemungkinan menjadi tidak subur(Bazargani and Fardyazar, 2006).

Penelitian yang dilakukan Cakir M, 2007 diTurki menemukan bahwa disminore merupakan gangguan menstruasi dengan prevelensi terbesar $(89,5 \%)$ diikuti tidak teraturan menstruasi $(31,2 \%)$, serta perpanjangan durasi menstruasi (5,3\%).Pada pengkajian terhadap penelitian-penelitian lain didapatkan prevalensi dismenorea bervariasi antara $15,8-89,5 \%$, dengan prevalensi tertinggi pada remaja. Mengenai gangguan lainnya.Polandia mendapatkan prevalensi amenorea primer sebanyak $5,3 \%$, amenorea sekunder 18,4\%, oligomenorea $50 \%$, polimenorea $10,5 \%$, dan gangguan campuran sebanyak $15,8 \%$. Jadi pada penelitian tersebut amenorea sekunder menduduki peringkat kelima gangguan menstruasi yang sering dialami wanita (Sianipar, dkk, 2009).

Secara nasional pada tahun 2013 terdapat akseptor KB sebanyak 663.254 akseptor, 334.217 akseptor suntikan (50,39\%), akseptor suntik 60,3\% (201.532) diantaranya memnggunakan DMPA (3 bulan) dan 39,7\% (132.685)menggunakan Cyclofem (1 bulan) dan $70,8 \%$ dari akseptor kontrasepsi suntik menggalami gangguan menstruasi yaitu amenorea sekunder(Riskesdas, 2010).

Data Provinsi Sulawesi Tenggara pada tahun 2013 didapatkan 284.783 akseptor suntik dan $59 \%$ (163.192) memakai DMPA dan $41 \%$ (116.761)menmakai cyclofem dan 70,8\% dari akseptor suntik diantaranya mengalami amenorea sekunder. Data Kabupaten Konawe didapatkan jumlah akseptor kontrasepsisuntiktahun 2013yaitu 36,44\% peserta dari 4.605 PUS, dan 58,3\% diantaranya mengalami amenorea sekunder. Pada tahun 2014 jumlah PUS yang diperoleh sebanyak 4.858 pasangandengan jumlah akseptor suntik37,07\% akseptor dari keseluruhan jumlah PUS dan 75,87\% diantaranya mengalami amenorea sekunder (BKKBN, 2013).

Pencapaian peserta kontrasepsi di kecamatan Lelembuu tahun 2014 tercatat 2541 peserta yang memakai alat kontrsepsi. diantaranya, MOW 76 orang, IUD 3 orang, pil 825 orang, kondom 13 orang, implant 345 orang, suntik 1281 orang dan 45,2\% (580) menggunakan kontrasepsi DMPA dan 54,8\% (701) menggunakan cyclofem $60 \%$ diantaranya mengalami amenorea sekunder.
Dilihat dari data-data di atas, pada penelitian ini, peneliti juga tertarik untuk meneliti hubungan pemakaian kontrasepsi suntik dengan amenorea diwilayah kerja Puskesmas Atari Jaya Kecamatan Lalembuu kabupaten Konawe selatan tahun 2015.

\section{METODE}

\section{Jenis Penelitian}

Jenis penelitian ini adalah penelitian kuantitatif, penelitian ini menggunakan desain observasional analitik denganpendekatan cross sectional untuk mempelajari hubungan antara kontrasepsi suntik dengan amenorea sekunder.

\section{Lokasi dan Waktu Penelitian}

Penelitian ini telah dilaksanakan diwilayah kerja Puskesmas Atari Jaya Kecamatan Lalembuu Kabupaten Konawe salatan. Waktu penelitian dilakukan pada bulan Mei 2015.

\section{Populasi dan Sampel.}

Populasi dari penelitian ini adalah semua akseptor suntik di wilayah kerja Puskesmas Atari Jaya Kecamatan Lalembuu Kabupaten Konawe Selatan yang berjumlah 1281 akseptor tahun 2015.

Sampel dalam penelitian ini adalah semua akseptor suntik yang di wilayah kerja Puskesmas Atari Jaya Kecamatan Lalembuu Kabupaten Konawe Selatan

\section{Pengumpulan Data}

Data primer adalah data yang diperoleh langsung dari responden melalui pengisian lembar kuesioner maupun wawancara yang meliputi data tentang hubungan pemakaian kontrasepsi suntik dengan kejadian amenorea sekunder.

Data sekunder adalah data yang diperoleh dari instansi terkait yang berhubungn dengan penelitian ini. Data sekunder kartu status peserta $\mathrm{KB}$.

\section{Pengolahan dan Analisis Data}

Pengolahan data penelitian ini yaitu Editing , Koding , Skoring, Entri,Tabulating .Setelah selesai pembuatan kode selanjutnya dilakukan pengolahan data kedalam satu tabel mennurut sifat - sifat yang dimiliki yang yang sama sesuai dengan tujuan penelitian ini. Tabel yang digunakan yaitu berupa tabel distribusi frekuensi. 
Analisis data penelitian ini yaitu Analisis univariat bertujuan untuk menjelaskan atau mendeskripsikan karakteristik setiap variabel penelitian. Pada umumnya dalam analisis ini hanya menghasilkan distribusi frekuensi dan presentase dari tiap variabel (Notoadmodjo, 2010) dan Analisis bivariant adalah analisis yang dilakukan untuk mengetahui masing-masing variabel, yaitu menghubungkan kontrasepsi suntik dengan Kejadian Amenorea menggunakan uji statistic Chie Squere dengan menggunakan batas kemaknaan $\alpha \leq 0,05$ artinya apabila diperoleh nilai $p$ value $\leq 0$. 05 berarti secara signifikan ada hubungan antara variabel independent dengan dependent dan jika nilai $p$ velue $\geq 0.05$ berarti tidak ada hubungan antara variabel independent dengan dependent (Notoanmodjo, 2005).

\section{HASIL}

Berdasarkan hasil penelitian yang telah dilakukan diPosyandu Puskesmas Atari Jaya Kecamatan Lalembuu Kabupaten Konawe Selatan pada tanggal 25 mei -15 juni 2015. Dengan jumlah sampel 92 orang yang memakai kontrasepsi suntik baik 1 bulan maupun yang 3 bulan dan yang menderita amenorea. Setelah data tersebut dikumpulkan, kemudian dilakukan pengolahan sesuai dengan penelitian, selanjutnya dibahas dalam bentuk tabel serta penjelasan sebagai berikut.

Tabel 1. Distribusi aksepsor kontrasepsi suntik di Wilayah Kerja Puskesmas Atari Jaya, Kecamatan Lalembuu, Kabupaten Konawe Selatan tahun 2015.

\begin{tabular}{ccc}
\hline Jenis kontrasepsi & Frekuensi & Presentasi \\
$\mathbf{3}$ bulan & 58 & $63,0 \%$ \\
$\mathbf{1}$ bulan & 34 & $37,0 \%$ \\
Total & 92 & $100 \%$ \\
\hline
\end{tabular}

Sumber : Data Primer, 2015

Berdasarkan tabel diatas dari 92 akseptor suntik, 58 aksepsor kontrasepsi suntik 3 bulan $(63,0 \%)$ dan 34 akseptor yang memakai kontrasepsi suntik 1 bulan $(37,0 \%)$.

Tabel 2. Distribusi Berdasarkan Kejadian Amenorea di Wilayah Kerja Puskesmas Atari Jaya Kecamatan Lalembuu, Kabupaten Konawe Selatan

\begin{tabular}{ccc}
\hline Amenorea & Frekuensi & Presentasi \\
\hline Primer & 15 & $16,3 \%$ \\
Sekunder & 77 & $83,7 \%$ \\
Total & 92 & $100 \%$ \\
\hline
\end{tabular}

Sumber : Data Primer, 2015

Berdasarkan tabel 2 dapat diketahui kejadian amenorea sekunder pada 92 akseptor dimana sebanyak 15 (16,3\%)akseptor diantaranya mengalami amenorea primer, sedangkan $77 \quad(83,7 \%)$ akseptor lainnya mengalami amenorea sekunder. 
Tabel 3.Hasil Analisis Bivariant Antara Kontrasepsi Suntik Dengan Kejadian Amenorea Sekunder Diwilayah Kerja Puskesmas Atari Jaya Kecamatan Lalembuu Kabupaten Konawe Selatan Tahun 2015

\begin{tabular}{|c|c|c|c|c|c|c|c|c|}
\hline \multirow[t]{3}{*}{ No } & \multirow{3}{*}{$\begin{array}{c}\text { Jenis } \\
\text { kontrasepsi }\end{array}$} & \multicolumn{4}{|c|}{ Amenorea sekunder } & \multicolumn{2}{|c|}{ Jumlah } & \multirow[t]{3}{*}{$\mathbf{F}$} \\
\hline & & \multicolumn{2}{|c|}{$\begin{array}{l}\text { Amenorea } \\
\text { Primer }\end{array}$} & \multicolumn{2}{|c|}{$\begin{array}{c}\text { Amenorea } \\
\text { Sekunder }\end{array}$} & & & \\
\hline & & $\mathrm{n}$ & $\%$ & $\mathrm{n}$ & $\%$ & $\mathrm{n}$ & $\%$ & \\
\hline 1 & 3 bulan & 0 & & 58 & $75,3 \%$ & 58 & $63,0 \%$ & 0,000 \\
\hline 2 & 1 bulan & 15 & $100 \%$ & 19 & $24,7 \%$ & 34 & $37,0 \%$ & \\
\hline Jumlah & & 15 & $100 \%$ & 77 & $100 \%$ & 92 & $100 \%$ & \\
\hline
\end{tabular}

Sumber : Data Primer, 2015

Berdasarkan tabel diatas dari 92 akseptor kontrasepsi suntik yang datang di posyandudan mengeluhmengalami amenorea sekunder sebanyak 77 akseptor $58(75,3 \%)$ diantaranya memakai kontrasepsi suntik 3 bulan dan $15(16,3,7 \%)$ lainnya memakai kontrasepsi 1 bulan sedangkan yang mengalami amenorea primer sebanyak 15 akseptor dan semuanya memakai kontrasepsi suntik 1 bulan, tidak ada akseptor kontrasepsi suntik 3 bulan yang mengalami amenorea primer.

Berdasarkan tabel diatas nilai $\rho_{\text {value }}=$ 0,000 yang berarti lebih kecil dari nilai $\alpha=$ 0,05 dapat disimpulkan terdapat hubungan kontrasepsi suntik dengan kejadian amenorea sekunder.

\section{PEMBAHASAN}

Penelitian ini dilaksanakan dipuskesmas Atari Jaya Kecamatan Lalembuu Kabupaten Konawe Selatan Tahun 2015. Berdasarkan Hasil penelitian yang diperoleh nilai $\rho=0,000<0,05$ yang menunjukkan bahwa ada hubungan kontrasepsi suntik dengan kejadian amenorea sekunder di puskesmas Atari Jaya Kecamatan Lalembuu Kabupaten Konawe Selatan tahun 2015. Hasil pengolahan analisis pada tabel 3 menyatakan bahwa pemakaian kontrasepsi suntik 3 bulan mempunyai resiko 8,9 kali mengalami amenorea sekunder bila dibandingkan dengan akseptor kontrasepsi suntik 1 bulan.

Hasil penelitian tersebut menunjukkan bahwa akseptor suntik DMPA banyak mengalami gangguan menstruasi hal ini disebabkan karena suntik DMPA hanya mengandung hormon progesterone saja dimana kandungan progesterone tersebut dapat menyebabkan gangguan menstruasi sedangkan amenore yang tinggi disebabkan karena hormon progesterone menekan LH sehingga endometrium menjadi lebih dangkal dan mengalami kemunduran sehingga kelenjarnya menjadi tidak aktif.

Hasil penelitian ini didukung oleh penelitian yang dilakukan Bazargani dan Fardyazar yang menyatakan bahwa efek pemakaian kontrasepsi suntik terhadap amenorea sekunder bertambah besar seiring dengan lamanya waktu pemakaian. Selain itu, hasil penelitian epidemiologis lain yang dilakukan oleh Sathyamala juga menunjukkan bahwa kejadian amenorea sekunder lebih sering dialami oleh akseptor kontrasepsi 
DMPA uyang melakukan penyuntikan ulang kontrasepsi (Phadke, 2005).

Hasil penelitian ini jugadidukung degan penelitian lain yang dilakukan oleh kaunitz (2001), kejadian amenorea sekunder pada akseptor kontrasepsi DMPA disebabkan oleh efek samping farmakologik kontrasepsi tersebut. Kadar obat kontrasepsi MPA yang dilepaskan secara perlahan dari Depo akan bersirkulasi dalam darah, sehingga mampu menekan pembentukan LH di Hipofisis. Penghambatan ini menimbulkan kegagalan ovulasi dan akhirnya tidak terjadi siklus menstruasi (amenorea). Selain itu tidak adanya

ovulasi mengakibatkan kadar estradiol serum juga tetap dipertahankan rendah akibat tidak meningkatnya kadar FSH secara simultan.

Pemakaian alat kontrasepsi suntik akan berpengaruh pada pola menstruasi. Hal ini juga didukung oleh Derision Marsinova (2005) bahwa sebagaian besar akseptorkontrasepsi suntik mengalami perubahan pola menstruasi, karena dengan memakai kontrasepsi suntik dalam jangka waktu lama, maka pertumbuhan endometrium semakin kecil dan terjadi atrofi endomentrium. Hal ini sejalan dengan penelitian yang dilakukan oleh andi yuliana (2010) yang menyatakan bahwa pola menstruasi dipengaruhi oleh faktor jenis alat kontrasepsi dan jangka waktu pemakaian.

\section{DAFTAR PUSTAKA}

Arikunto S, 2006. Prosedur Penelitian Suatu Pendekatan Praktik, Ed Revisi VI, Penerbit PT Rineka Cipta, Jakarta.

Arikunto, S. 2010. Prosedur Penelitian Suatu Pendekatan Praktik. Jakarta: Pt Rineka Cipta.

Arum, Dns., Dan Sujuyatini. 2009. Pandangan Lengkap Pelayanan $\mathrm{Kb} \quad$ Terkini.Jogyakarta:Nuha Medika.

Bazargani H.S.2006. Amenorhea An Advantage Rather Than A Complication Of Depot Medroxy Progesterone Acetate Anjectable
Kontrasepsi hormonal dapat mempengaruhi organ seks wanita. Organ yang paling banyak mendapat pengaruh adalah endometrium, miometrium, serviks dan panyudara. Perubahan hormonal dapat menimbulkan pengaruh terhadap siklus menstruasi. Hasil penelitian ini menunjukkan bahwa alat kontrasepsi berpengaruh terhadap perubahan pola menstruasi akseptor tersebut.

\section{KESIMPULAN DAN SARAN}

Dari hasil penelitian pada 92 responden terbanyak menggunakan kontrasepsi suntik 3 bulan yaitu $58(63,0 \%)$ responden. Berdasarkan hasil penelitian dari 92 responden terbanyak pada ibu yang mengalami amenorea sekunderyaitu 77 ( 83,7\%) responden. Kesimpulan dari penelitian ini yaitu ada hubungan kontrasepsi Suntik Dengan Kejadian Amenorea Sekunder di Wilayah Kerja Puskesmas Atari Jaya Kecamatan Lalembuu Kabupaten Konawe Selatan Tahun 2015.

Saran dari hasil penelitian ini yaitu bagi tenaga kesehatan agar selalu lebih sering sosialisasi tentang dampak kontrasepsi suntik pada para akseptor di posyandu. Bagi peneliti selanjutnya diharapkan hasil penelitian ini dapat digunakan untuk menambah khasanah ilmu kebidanan dan dapat dijadikan bahan rujukan serta dapat melakukan penelitian lebih lanjut dengan metode penelitian dan vareabel yang berbeda sehingga dapat menutupi kekurangan pada penelitian ini.

Contraseptive, Antl; J. Pharnacol. 2 (6) 352-354.

Baziad, A. 2002. Kontrasepsi Hormonal. Jakarta. Bina Pustaka Sarwono Prawirohardjo

Bielak, K.M. 2008. Amenorea. $\mathrm{Http} /$ Medicine,Mediscape.Com (25 Januari 2015).

BKKBN,KB Suntik Paling di Gemari IbuIbu, 2013. http://m.kompas/news/readDiakse s tanggal 1 Januari 2015

Boroditsky, Lera. 2000. "Metaphoric Structuring: Understanding Time 
Through Spatial Metaphors," Cognition, 75, 1-27.

Cunningham F.G. 2005 Obstetri Williams. Hartanto,H. (Eds). Edisi 21 Volume 2 Jakarta: EGC.Pp 17147.

Depkkes. Ri. 2001. Kesehatan Reproduksi. Jakarta.

Hanafi, Hartanto. (2003). Keluarga Berencana Dan Kesehatan Reproduksi. Jakarta : Pustaka Sinar Harapan.

Hartanto, H. 2004. Keluarga Berencana dan Kontrasepsi. Jakarta: Pustaka Sinar Harapan.

Hartanto, H., 2009, Keluarga Berencana dan Kontrasepsi, Jakarta: Pustaka Sinar Harapan: 212-213.

Hatcher R.A,Trussell J, Nelson A.L. 2009. Contraseptive Technology. Edisi19. Usa. Ardet Media Inc, pp:157-69;461-5

Heffner L.J. Dan Schust D.J. 2006. At A Glancesistem Reproduksi. Safitri S (Ed). Edisi 2. Jakarta; Penerbit Erlangga, Pp:68-71

Hillegas K.B. 2005. Gangguan Sistem Reproduksi

Perempuan.Dalam:Price S.A Dan Wilson L.M. Patofisiologi: Konsep Klinis Proses-Proses Penyakit.Hartanto H. Dkk(Eds). Edisi 6.Volume 2. Jakarta:Penerbit Buku Kedokteran Egc, Pp:1280-7

Kaunitz A. 2001. Injectable Long-Acting Contrseptive. Clin Obstet Gynecol 44:73-91

Notoatmodjo.S. 2005. Metodologi Penelitian Kesehatan. Jakarta; Rineka Cipta.

Notoatmodjo, S. 2010. Metodologi Penelitian Kesehatan. Jakarta : Rineka Cipta
Pinem,S.2009. Kesehatan Reproduksi Dan Kontrasepsi. Jakarta:Trans Info Media.

Prawirohardjo, Sarwono. 2008. Ilmu Kandungan. Jakarta : Yayasan Bina Pustaka.

Riyanto, A. 2011. AplikasiMetodologi Penelitian Kesehatan.Yogyakarta: Nuha Medika.

Saifuddin, A.B., B. Affandy, \& Enriquito, R. LU., 2003, buku Panduan Praktis Pelayanan Kontrasepsi Edisi 1, Jakarta: Yayasan Bina Pustaka Prawirohardjo.

Sastroasmoro, Sudigdo \& Sofyan Ismael. 1995. Dasar-Dasar Metodologi Penelitian Klinis. Jakarta: Binarupa Aksara.

Seifert, Kurt., Camacho Oscar. (2007), Implementing Positioning Algorithms .

Sinclair. Constance.2009.Buku Saku Kebidanan.Jakarta : EGC

Sherwood L. 2001. Fisiologi Manusia Dari Sel Kesistem. Santoso B.I.(Ed). Edisi 2. Jakarta: Penerbit Buku Kedokteran Egc, Pp:713:726-7.

Speroff L.Glass R.H.Kase N.G.., 2007.Clinical Gynecology Endocrinology And Infetility. $6^{\text {th }}$ Ed. Philadelphia:Lipponcott Williwms\& Wilkins, Pp:40537;911-12;949-74. Using Accelerometers, Freescale Semiconductor, Rev 0.

Suratun,maryani,Sri . 2008. Pelayanan Keluarga Berencana dan Pelayanan Kontrasepsi. Jakarta: Trans Info Media: 15-16, 19, 8789.

Wiknjosastro, H. 2006. Ilmu Kebidanan. Jakarta: Yayasan Bina Pustaka Sarwono Prawirohardjo;P.181191 